\title{
RETRACTED ARTICLE: Fabrication of Lotus-Type Porous Al-Si Alloys Using Thermal Decomposition Method Combined with Mold Casting and Continuous Casting Techniques
}

\author{
TAE BUM KIM, TAEK KYUN JUNG, YONG HWAN KIM, TAEK SOO KIM, \\ and SOONG KEUN HYUN
}

DOI: $10.1007 / \mathrm{s} 11663-013-9878-9$

(C) The Minerals, Metals \& Materials Society and ASM International 2013

THE submitting author of this paper incorrectly identified his coauthors. The actual coauthors, who are not listed on the paper, do not agree with the technical content of the paper, and so it has been retracted.

TAE BUM KIM and TAEK KYUN JUNG, Researchers, YONG HWAN KIM and TAEK SOO KIM, Principal Researchers, are with the Korea Institute of Industrial Technology, Incheon, Korea. Contact e-mail: xoqja78@kitech.re.kr SOONG KEUN HYUN, Professor, is with the Inha University, Incheon, Korea.

Manuscript submitted January 20, 2013.

Article published online May 29, 2013. 